Article

\title{
The Segmentation of the Academic Labour Market and Gender, Field, and Institutional Inequalities
}

\author{
Marta Vohlídalová \\ AMBIS University, Czech Republic; E-Mail: marta.vohlidalova@centrum.cz \\ Submitted: 15 February 2021 | Accepted: 16 June 2021 | Published: 21 July 2021
}

\begin{abstract}
Using data from a 2017 survey of Czech academics this article examines the casualisation of working conditions in the Czech academic labour market (ALM) and explores gender, sectoral, and institutional inequalities through the lens of the theory of labour market segmentation. A hierarchical cluster analysis reveals three segments in the Czech ALM: core (40\%), periphery (28\%), and semi-periphery (32\%), which roughly align with work positions in the early, middle, and senior stages of an academic career. In the semi-periphery gender is found to be a key factor in in determining working conditions, while in the periphery working conditions are most affected by the type of institution. In the core, gender differences are mainly reflected in the gender wage gap. The effects of casualisation on working conditions are found to be more pronounced in STEM fields than in the social sciences and humanities across the ALM, but wages are generally higher in STEM fields.
\end{abstract}

\section{Keywords}

academia; inequalities; labour market segmentation; neoliberalism; work conditions

\section{Issue}

This article is part of the issue "Inclusive Universities in a Globalized World" edited by Liudvika Leišyte (TU Dortmund, Germany), Rosemary Deem (Royal Holloway, UK) and Charikleia Tzanakou (Oxford Brookes University, UK).

(C) 2021 by the author; licensee Cogitatio (Lisbon, Portugal). This article is licensed under a Creative Commons Attribution 4.0 International License (CC BY).

\section{Introduction}

Academic labour markets (ALM) in most countries have become more dynamic and competitive in recent decades but have simultaneously seen working conditions deteriorate (see, e.g., Kwiek \& Antonowicz, 2015; Musselin, 2005). These trends mainly impacted earlycareer academics in the past, but senior academics are increasingly affected as well (Kwiek \& Antonowicz, 2015; O'Keefe \& Courtois, 2019). The casualisation of working conditions in academia amidst the neoliberal transformation of ALM has thus become an important topic of research (e.g., Bauder, 2006; Fumasoli et al., 2015; Ivancheva, 2015; Kimber, 2003; Ylijoki, 2010).

Research on the ALM's transformation and the working conditions of academia has shown that the casualisation of academic work negatively affects women more than men (e.g., Dubois-Shaik \& Fusulier, 2017; Fox et al., 2017; Ivancheva et al., 2019; Vohlídalová \& Linková, 2017; Zheng, 2018). But there has been less research on the gender-specific effects of the ALM's transformation on working conditions in different fields and types of academic institutions. Field and institution are both factors that affect ALM conditions (see, e.g. Fumasoli \& Goastellec, 2015; Passaretta et al., 2019; Ylijoki et al., 2011) and compound gender inequalities (Cidlinská, 2019; Wolf-Wendel \& Ward, 2014).

My analysis draws on segmentation theory (Bauder, 2006; Leontaridi, 1998). The theory distinguishes between the more and less privileged segments of the labour market, which are exposed to the negative effects of the transformation of ALM to differing degrees. I focus on the 'horizontal dimension' of the casualisation of work conditions and examine, first, how gender, field, and institution affect working conditions in different ALM segments and, second, how ALM segments differ from each other.

The article contributes to current research on the ALM's transformation and casualisation in several ways. First, it compares how gender, field, and institutional inequalities are manifested in different segments of the ALM instead of focusing on one ALM segment 
(e.g., early-career women academics or seniors are common focus topics in the current literature; see, e.g., Bagilhole \& Goode, 2001; Bataille et al., 2017; Bozzon et al., 2017; Cidlinská, 2019; O’Connor, 2010). Second, it provides insight into ALM segmentation beyond the traditional core-periphery division defined by type of employment contract, full-vs part-time work, or tenured vs non-tenured staff. It proposes an innovative methodology for studying the ALM's structure that considers the cultural specifics and differences between institutions, fields and career systems. Third, since it is based on the Czech case, it contributes to the scant body of research in this area devoted to a CEE country, as most studies are based on the Anglosphere or Western Europe (exceptions include, e.g., Fumasoli et al., 2015; Luczaj, 2020; Vohlídalová \& Linková, 2017).

My analysis is based on a representative survey of 1710 Czech academics conducted in 2017. The sample included people employed in academic research or teaching positions (or both) at public universities (HEIs) and at the public research institute Czech Academy of Sciences (CAS).

There are several reasons why a study focusing on the Czech Republic may be of broader interest. The Czech academic landscape is diverse in terms of its institutions and is thus an excellent case for exploring how the casualisation of work conditions impact different types of institutions. It does not have a 'tenure-track' career system like that in the Anglosphere. It has multiple career systems, which make it hard to define the boundaries between different ALM segments. My proposed methodology may therefore be useful for research on other countries where it may be difficult to distinguish between different ALM segments.

The Czech academic landscape also offers an excellent opportunity to study gender inequalities. According to European comparative data, the Czech Republic is one of the worst countries for gender equality in academia: while $42.7 \%$ of PhD graduates in 2017 were women, only $26.9 \%$ of researchers were women (the number has not changed since 2001; European Commission, 2019). Women occupy $14.6 \%$ of A-grade positions (fullprofessors), compared to $23 \%$ in the EU-28 (European Commission, 2019). There is also no governmental policy to support women in academia.

Although an outlier in some respects, what we see in the Czech Republic is consistent with global trends in the transformation of the ALM. Czech academia has been undergoing a neoliberal transformation since 2008, when R\&D reforms introduced a focus on competition (Linková, 2017). The long-term block grants that used to be awarded to research institutions have since been significantly reduced and institutions have become dependent on competitive grant funding (Linková \& Stöckelová, 2012), which is common in most academic environments today (Kwiek \& Antonowicz, 2015). Czech academia is now exceptional for the central role played by competitive grant funding (up to $70 \%$ of all funding in the case of some institutions; see Cidlinská, 2019). Stable independent research jobs have been replaced with projectbased positions that require extreme mobility (geographical, temporal) and offer short-term work contracts and financial insecurity (Linková, 2017). Data suggest that early-career researchers and women especially are increasingly being left in precarious academic positions (Vohlídalová, 2018), while the system reinforces the privileged job status of the older generation (Cidlinská, 2019).

Below I focus first on presenting segmentation theory and its benefits for ALM research and then discuss current research into the quality of employment and the casualisation of ALM by field, institution, and gender. In the methodological section, I describe the data and methods used to define and analyse segments of the ALM, and I conclude the article with a discussion of the findings and conclusions.

\section{Segmentation Theory and the Academic Labour Market}

The deterioration of working conditions in the ALM is linked to the massification of university education. The number of PhD graduates is growing much faster than the supply of jobs in R\&D, which makes the ALM extremely competitive, especially in the early-career stage (European Commission and Eurydice Network, 2017; Fumasoli et al., 2015). The ALM relies on there being a large stock of highly skilled, gifted, and motivated people willing to perform academic work as a 'labour of love' and to work a lot for little money (Cidlinská \& Linková, 2013). They perform the various tasks that are essential for academic institutions to operate smoothly and for tenured core staff to advance their careers.

The rise of neoliberalism in academia has exacerbated the decline in working conditions. The neoliberal transformation of academia under the influence of managerialism and New Public Management has spread from the Anglosphere to most other academic communities, which are then collectively characterised by the pressure to perform, an audit culture, and increased competition for funding (Leišytė, 2016; Linková, 2017; Shore, 2008; Shore \& Wright, 2015). The increasing instability of public funding in academia had led to a sharp decline in working conditions (Linková, 2017).

The theory of labour-market segmentation (Leontaridi, 1998) is a useful tool for explaining growing inequalities in the ALM and the fact that different types of academics are affected by the aforementioned trends to different degrees. It distinguishes between the centre of ALM (the 'tenured core') and its 'casualised periphery.' The centre is shielded from the risks caused by the new working conditions, but the growing periphery is fully exposed (e.g., Bauder, 2006; Finnegan, 1993; Kimber, 2003; May et al., 2013). Academics on the 'casualised periphery' face permanent job insecurity, poor career prospects, short-term employment contracts, heavy workloads, low wages and social benefits, and little 
opportunity to participate in decision-making and thus address their negative job conditions (Bauder, 2006).

The purpose of labour-market segmentation generally is to protect firms from insecurity: The 'core' consists of permanent staff, who are key to the firm's operation, while the 'periphery' is peopled with workers whose numbers can be flexibly changed as needed (Atkinson, 1984). This labour structure is common in industries that face high levels of instability (Leontaridi, 1998), which is the case of academia today. Casualisation has traditionally affected low-skilled workers in jobs where they can be easily replaced (Leontaridi, 1998). In academia, where most employees have a PhD or at least an MA, the 'easy-replacement-system' is sustained by an influx of large numbers of PhD candidates and graduates (Bauder, 2006; European Commission and Eurydice Network, 2017; Finnegan, 1993; Fumasoli et al., 2015). The casualisation of work does not just affect recent PhD holders and graduates only, as a UK study found that many women academics over 40, long after they obtained their doctorate, are in casualised positions as well (O'Keefe \& Courtois, 2019).

An important factor in the ALM system is that the segmentation of the labour market is not determined so much by a worker's performance but by the institutional barriers that hinder or block the mobility of academics into a more privileged segment (Leontaridi, 1998). The entire system draws its legitimacy from the ideology of 'research excellence,' a concept associated with meritocratic principles but found in most literature to be highly selective and gender-biased (Linková, 2017; van den Brink \& Benschop, 2011, 2012). It systematically devalues the tasks performed by academics in lower-ranking positions (e.g., teaching, academic housework, research execution), while these tasks are what prevent them from concentrating on research and publishing (Courtois \& O'Keefe, 2015; O'Keefe \& Courtois, 2019; Shore, 2008).

The boundary between the core and the periphery based on the division between tenured faculty and nontenured staff is used in the Anglosphere. The periphery tends to be characterised by part-time and temporary work (see, e.g., Kimber, 2003; May et al., 2013, both studies based on Australia). May et al. (2013, p. 259) define 'casuals' as "hourly paid staff who teach in universities." The core includes permanent academic staff, who receive a regular salary and have access to leave benefits, regardless of what type of work contract they have. Other definitions include Bauder's (2006, Canada) and focused mostly on part-time and fixed-term contracts, and Kimber's (2003), who also considers job content (teaching-only functions). Ivancheva (UK and Ireland) speaks about the "reserve army of workers with ever shorter, lower paid, hyper-flexible contracts" (Ivancheva, 2015 , p. 39). Estimates of the size of the casual periphery thus differ by the criteria used to define it. What is undisputed, however, is that it is growing at the expense of stable academic jobs with career prospects (Bauder,
2006; Ivancheva, 2015; Ivancheva et al., 2019; Kimber, 2003; May et al., 2013).

Only $35 \%$ of Czech academics have permanent contracts, while $58 \%$ have fixed-term contracts (compared to just $8 \%$ of non-academic workers), and the rest have various short-term contracts. Around $26 \%$ of respondents work part-time (Vohlídalová, 2018), but not all of them are equally precarious. Some academics with fixed-term contracts are not part of the casualised periphery, as their contracts are regularly renewed. Some well-established scholars also voluntarily combine part-time work at an HEI with research work at the CAS. Consequently, the core-periphery distinction based only on type of contract, working hours, or job content is thus not universally applicable.

\section{ALM Casualisation in Relation to Gender, Field and Type of Institution}

\subsection{Gender Inequalities}

Despite the growing numbers of women $\mathrm{PhD}$ graduates in recent decades, they are significantly underrepresented in academic positions (European Commission, 2019). This is changing in some countries and the representation of women in academic positions is increasing, but women remain mostly in disadvantaged positions (European Commission and Eurydice Network, 2017). There are also comparatively few women in higherranking academic posts and in decision-making bodies (European Commission, 2019). Their career-progress conditions are also worse: They are more often than men found working part time, on short-term contracts, in non-tenure track jobs, and in teaching-intensive positions (Fox et al., 2011; González Ramos et al., 2015; Wilson \& Nutley, 2003; Wolfinger et al., 2009). Women are more often burdened with teaching duties and academic 'housework' (Macfarlane \& Burg, 2019), which disadvantages them in a competitive labour market where career progress is based mostly on research performance, publications, and getting external funding (Kwiek \& Antonowicz, 2015). Women receive less mentoring support from senior tutors, which is especially important for career advancement today (Kwiek \& Antonowicz, 2015; van den Brink \& Benschop, 2014).

Despite the increasing share of women academics, academia is still a very male-oriented organisational environment that favours the traditional male biography, free from care duties, and favours people who can devote all their time to the job (Acker, 1990). Women (and many men as well) have difficulty conforming to the favoured career path of steady, upward progress achieved through competition and flexibility, which often clashes with family and private life (Fox et al., 2011, 2017; Mason \& Goulden, 2004; Wolfinger et al., 2009). Women also face discrimination and stereotypes (Wennerås \& Wold, 1997) and are disadvantaged by the gendered division of work in the family 
(Mason \& Goulden, 2004). The work-life conflict can even be reinforced by social and institutional policy settings (Dubois-Shaik \& Fusulier, 2017; Fox et al., 2017; Vohlídalová, 2020).

\subsection{Field}

The norms, culture, and expectations that define the ideal career path and work performance differ between disciplines (Becher \& Trowler, 2001; Fumasoli \& Goastellec, 2015). The neoliberal transformation has also unsurprisingly advanced to different degrees in different disciplines (and institutions), with the effects more pronounced in STEM fields than in the social sciences and humanities (SSH; see, e.g., Fumasoli \& Goastellec, 2015; Ylijoki et al., 2011).

STEM fields tend to be dominated by a work model that can be described as a 'dynamic laboratory,' where the lab-leader is the only long-term member of a research team, and doctoral students and postdocs occupy short-term positions, which used to be held by more senior independent researchers. SSH fields are dominated by the 'dynastic laboratory' model, where senior researchers are still long-term members of a research teams (Linková \& Červinková, 2013).

This does not mean that career prospects and professional satisfaction are worse in STEM. Jackson et al. (2017) found in the UK that academics in STEM are happier with the promotion process than those in SSH. An Italian study exploring the effects of government budgetary cuts on the academic careers of fresh PhD holders revealed that STEM graduates have a better chance of staying in academia than those in SSH (Passaretta et al., 2019).

The intersection between gender and academic field is particularly important. STEM fields are the most challenging environment for women academics (Durodoye et al., 2020; Rhoton, 2011), a fact illustrated by the small share of women in this sector (European Commission, 2019). The gender gap in STEM can be attributed to its strongly masculine work culture, the ethics of total self-dedication to science, and the lack of women role models among other factors (see, e.g., Bagilhole \& Goode, 2001; Rhoton, 2011).

In the Czech Republic, STEM fields are favoured over $\mathrm{SSH}$, so we can assume that field has an important effect on work conditions. SSH fields account for $11.5 \%$ of all academic employees but only $6.3 \%$ of total research expenditures (Czech Statistical Office, 2020). SSH fields are also much less prestigious than STEM fields for historical reasons in the Czech Republic (Oates-Indruchová, 2008), and because its research is popularly considered more useful given its practical applications.

\subsection{Type of Institution}

Working conditions are affected by the organisational context, which refers to funding and an organisation's culture and climate (Fumasoli \& Goastellec, 2015). Although all academic institutions have witnessed the casualisation of work, its effects may vary between organisations. Ylijoki et al. (2011), in a study on Finland, showed that the scale of the effects of marketisation and the neoliberal transformation depends on the type of institution, with teaching-oriented and SSH institutions being more resistant to these tendencies than STEM researchoriented institutions.

The Czech academic landscape is diverse and alongside public HEls, devoted to teaching and research, there are also public research institutes (PRIs) that do only research-the CAS is the umbrella organisation of the country's most significant PRIs. The CAS is funded by the government, but this funding mainly covers basic operational and some personnel costs ('core' and administrative staff salaries). The CAS's institutes get much of their funding (about 45\%) from competitive grants and other sources (CAS, 2020). The basic salaries in the CAS and in $\mathrm{HEls}$ are low but can be supplemented with grant funding. HEls have two sources of governmental funding: perstudent subsidies and research assessment-based subsidies. In HEls a key funding role is played by competitive grants (Šima \& Pabian, 2017).

At Czech HEls careers are built and job security attained not through tenure but through the "habilitation' procedure, which requires that academics teach and do research uninterruptedly for several years and then publicly defend their habilitation thesis (Mudrák et al., 2018; Šima \& Pabian, 2017). Associate and full professors occupy a privileged and secure position at Czech universities because the universities need them so that the study programmes fulfil the accreditation requirements (Šima \& Pabian, 2017). They are thus in a very different position from other university academics, who have precarious career prospects, low wages, and a gruelling workload (Mudrák et al., 2018).

\section{Data, Methods, and Variables}

The analysis is based on the results of a questionnaire survey "Academics 2017" fielded in 2017 among 1710 academic (teaching or research) staff in the public academic sector (HEls and the CAS). The Lime Survey platform was used to administer the survey; respondents were invited to participate in the survey by email and completed the questionnaire online.

Altogether 11,316 academics (5757 from the CAS and other PRIs and 5559 from HEIs) were contacted by email based on information about staff publicly available on institutional websites. The sample also included PhD candidates working at an HEI or PRI and listed among staff members on department websites (the sample did not include 'ordinary' PhD candidates with the status of students). The stratified random sampling copied the sector's structure. Sample representativeness was ensured in terms of gender, field, institution, and seniority.

The questionnaire was completed by 2089 respondents. Because of the low representation in our sample 
of academics working in PRIs outside the CAS, only academics from the CAS and HEIs ( $N=1881$ ) were included in the analysis, and of them only those who provided complete information on their work conditions ( $n=1710$ ). The survey response rate was $18.5 \%$.

Along with socio-demographics, institution, and field of study, the survey examined 'objective' working conditions (e.g., employment contract, job description, wages, teaching/research workload, etc.) and 'subjective' conditions (e.g., self-assessment of various aspects of workleadership, social climate, work-life balance, remuneration, gender equality, job security, etc.). The questionnaire was piloted.

The analysis first sought to identify similarities across academic positions in the ALM, that is, what working conditions and casualisation effects were more generally shared. A hierarchical cluster analysis helped determine which positions form the core and which are part of the casualised periphery. After assigning each position to an ALM segment, I focused on the gender, field, and institutional differences in work conditions within the individual ALM segments. I modelled a series of regressions (linear and binomial logistic) for each segment. The goal was to model the net effect of gender, field, and institution on the work-quality indicators used in the hierarchical cluster analysis (see Supplementary File for the results). SPSS software was used.

The different academic positions compared were based on the official career ladders used in different organisations. Positions at the CAS, in hierarchical order, are: (1) senior researchers and principal investigators, (2) research associates/postdocs, and (3) PhD candidates (with employee status). Positions at HEls are: (1) full/associate professors, (2) assistant professors, (3) postdocs/researchers, (4) lecturers/instructors, and (5) PhD candidates. I worked with 16 categories (some low-populated positions were merged in order to provide robust analysis), defined by combining seniority on the official career ladder, field, and type of institution (see Figure 1).

Similarities between positions were determined on the basis of employment quality characteristics. I partly adopted the UN's operationalisation, which encompasses 'objective' job characteristics (wage, type of contract) and variables based on employees' perceptions (United Nations, 2015). This then captures how two employees with objectively identical contracts or workloads may in fact have very different working conditions.

The hierarchical cluster analysis of dis/similarities between the 16 categories worked with the following variables (standardised in the analysis by z-scores; for details see Supplementary File, Table 1):

- Income: a position's average monthly wage.

- Job security: 'objective' characteristics (contract duration and stability, contract type) and a variable on respondents' 'subjective' perceptions of job security. Indicators included in the compara- tive analysis of job positions were the share of respondents in each position who (1) perceived their position as unstable, (2) had at least a threeyear employment contract, (3) were hired for a specific project only (contract research staff [CRS]).

- Time: the average number of hours usually worked during academic year per week in the position and the share of respondents in each position who (1) stated they often or very often had felt exhausted over the past 14 days and (2) had a fulltime work contract (i.e., 40h/week).

- Organisational citizenship: refers to an individual's integration within the organisation and his/her employee status, which lies outside such indicators as contract type or wage. Research (O'Keefe \& Courtois, 2019) indicates that people in the casualised periphery often feel like outsiders in their academic setting; they lack support from those around them and feel alienated and stuck in a position with no potential career growth. They often feel frustrated and dissatisfied, and that they are unfairly treated or lack job autonomy (O'Keefe \& Courtois, 2019). In the analysis $\mathrm{I}$ included the average ratings for each position that were assigned to (1) collegial support, (2) level of job autonomy, and (3) ability to put one's skills to use at work under the package of variables designed to determine 'organisational citizenship' (see Supplementary File, Table 1).

\section{The Core, the Periphery, and those in Between}

From the results of the hierarchical cluster analysis, we can clearly identify the positions that belong to the core and to the periphery, but many positions figured somewhere between the two (see Figure 1)-in a semiperiphery. The typology that emerged from the cluster analysis seems to reflect, with one exception, the career ladder: The core consists of senior academics, the periphery is formed mainly by PhD candidates, and middlecareer positions are in the semi-periphery. All the differences discussed below in the analytical part were tested statistically significant on the $\alpha=5 \%$, unless stated otherwise. Statistical significance was tested with the use of $X^{2}$ tests - in the case of contingency tables - and with T-tests/ANOVA-in the case of testing differences in mean values, unless stated otherwise. For details on statistical significances based on the regression models see Tables 1 and 2 in the Supplementary File.

\subsection{The Core}

Privileged positions in the core include full professors and associate professors in HEls and senior researchers at the CAS (the mean age of people in these positions was 49.7 for women, 52.2 for men).

This segment typically has the highest wages and few part-timers (17.2\%), and its part-time employment 


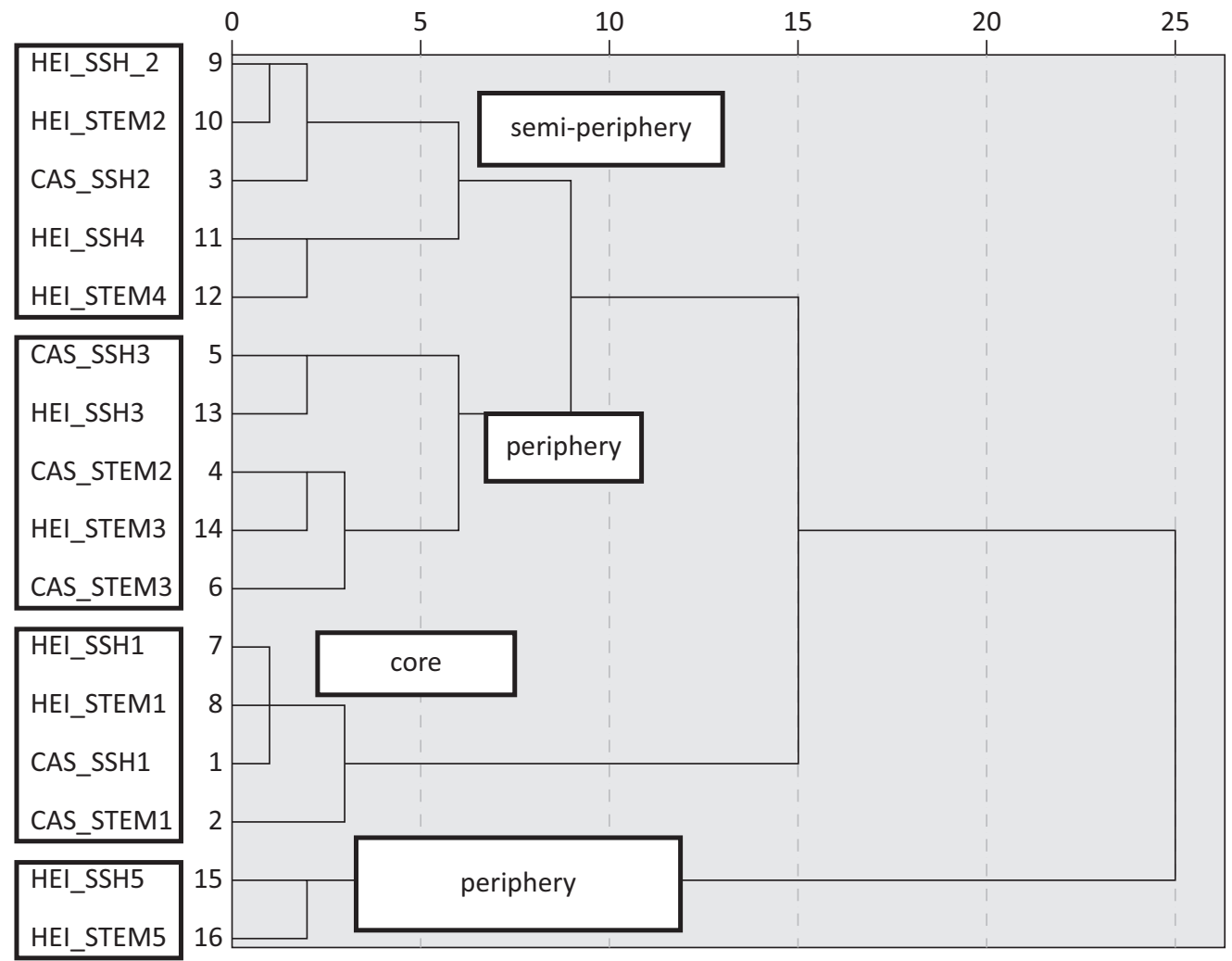

Figure 1. Dendrogram (ALM segments). Data from the "Academics 2017" survey.

is often the result of some factor other than not being offered a longer-hours contract (the latter reason was cited by $36.5 \%$ of part-timers in the core, compared to over $50 \%$ of those in the semi-periphery and over $66 \%$ in the periphery). The core has the highest level of job security, as most academics have at least a three-year employment contract, and a small share of CRS (24.1\%). Workers in the core have the most job autonomy and express the most satisfaction with how their skills are used at work. These positions form the privileged core of the ALM, where heavy job demands (on average 46 working hours per week; $42 \mathrm{~h} /$ week in the semi-periphery, $39 \mathrm{~h} /$ week in the periphery) are compensated with higher income, high autonomy, and high job stability. Less than $40 \%$ of our sample occupied these core positions, and most of them are men, who make up $68.8 \%$ of the core.

The regression analysis on the core segment (for details see Supplementary File, Table 2) revealed no gender differences in objective or subjective job security indicators. These differences were mainly determined by field and type of institution. HEI workers in core positions (i.e., HEl core academics) had much higher job security scores than the CAS-based senior researchers (CAS core academics). HEI core academics are $82 \%$ less likely than CAS core academics to be working as a CRS, twice as likely to have at least a 3-year employment contract, and $73 \%$ less likely to be worried about losing their job (after controlling for the effect of gender and field). As for differences between fields, CRS positions, even if they are in the core, are much more common in STEM than in SSH: Core academics in STEM are 5.4 times more likely to be CRS than core academics in SSH fields. This suggests that in STEM fields and CAS in particular increasing competitiveness even affects senior staff (Kwiek \& Antonowicz, 2015).

Women in the core earn less than their male counterparts; descriptive statistics indicate that men score on average 7.6 and women score on average 6.8 on a scale of 1 (lowest income level) to 11 (highest level). This remains true after controlling for the effects of field and institution. The gender differences in income were observed in STEM fields at both HEls and the CAS. Wages are generally higher in STEM than SSH fields, except in the periphery (average income levels in the core segment are 7.26 for STEM and 6.8 for SSH).

Women in the core have a lower official workload than men (the average 'official' workload was $35.6 \mathrm{~h} /$ week for women and $37.2 \mathrm{~h} /$ week for men) and lower wages, but this does not mean that they actually work fewer hours than men. When we focus on hours actually worked, the statistical significance of gender differences disappears. One reason for women's lower wages could be the fact that they more often occupy teaching-intensive positions (about $14.4 \%$ of women but only $6.7 \%$ of men in the core declared they were mainly or only engaged in teaching), which generally pay much less than research in the Czech Republic.

\subsection{The Semi-Periphery}

This segment is mainly made up of HEl-based assistant professors and CAS-based postdocs and research 
associates in SSH. HEl-based lecturers and instructors accounted for a small portion of semi-periphery academics ( $4.7 \%$ of our sample). Semi-periphery academics account for $32 \%$ of our sample and women slightly dominated in this group $(53.9 \%)$. The semi-periphery tends to provide higher income and job security than the periphery but is characterised by a heavy workload and the highest levels of reported exhaustion. Semi-periphery positions are rarely occupied by CRS (who make up just $11 \%$ of this segment), except at the CAS. There are more academics in the semi-periphery with long-term (3+ years) or permanent contracts than in the periphery. The semi-periphery has fewer part-timers than the periphery (24.6\%), but $50.4 \%$ of them stated they had never been offered a longer-hours contract. Many others, however, indicated other reasons for working part-time: a main job outside academia (25\%) or childcare (25.2\%).

The greatest gender-based inequalities are observed in the semi-periphery out of all the ALM segments and are found across a wide range of characteristics such as income, job security, and organisational citizenship. Like in the core, women in the semi-periphery earn statistically significantly lower wages than men. Gender differences were observed in both SSH and STEM fields and mainly at HEls, and not at the CAS. Like in the core, gender wage inequalities could not be attributed to differences in the hours actually worked or stated in the work contract, as no statistically significant differences by gender were observed in either case. This again may relate to the teaching workload in positions women occupy (about $50 \%$ of women but only $35 \%$ of men in the semi-periphery declared they were mostly or only engaged in teaching). This is particularly true for STEM fields, while in the SSH these differences are not statistically significant.

As in the core, STEM fields in the semi-periphery pay more than $\mathrm{SSH}$, but institution type has the opposite effect than in the core-CAS academics reported higher earnings than HEls academics (see Supplementary File, Table 1).

Gender exhibits a significant effect on job security characteristics in the semi-periphery. It doesn't affect the objective characteristics of job security (i.e., work contract, CRS), which are influenced mainly by field (there are more CRSs in STEM fields than SSH fields), but it does significantly affect the subjective perception of job security. Women were less satisfied with their job prospects; they had stronger concerns about losing their job and being able to find a new one. When we control other covariates, women are about $60 \%$ more likely than men to fear that they will not find a job and almost twice as likely to have strong concerns about losing their job (see Supplementary File, Table 2).

Gender plays a key role with respect to various aspects of job well-being and organisational citizenship. Women in the semi-periphery feel less autonomy at work than men. When we control for the effect of covariates, women are about $40 \%$ less likely than men to have control over an important aspect of their work (see Supplementary File, Table 2). They are also more likely to suffer from physical and mental exhaustion. If we control for the effect of field, institution, and PhD, women are 1.8 times more likely than men to report feeling of physical and mental exhaustion (see Supplementary File, Table 2). These differences might be linked to the stage in the life cycle that semi-periphery academics are: The mean age is 41.2 years for women and 40.3 years for men, the age when people are often also caring for children. The semi-periphery also exhibits the biggest gender differences in terms of time spent on housework and childcare: women spend 12.3 hours more per week than men on care/housework (8.9 hours/week more in the core and 6 hours/week more in the periphery).

My data also suggest that in the semi-periphery segment men are more often childless/free than women ( $35.4 \%$ of women but $41.1 \%$ men), in contrast to the core, where the opposite is true $(24.3 \%$ of women, but $17 \%$ of men were childless/free). This finding supports research (e.g., Hall, 2010) claiming that women in academia are more often childless/free than men and that this is most apparent at the senior academic level.

\subsection{The Periphery}

The casualised 'periphery' is largely made up of earlycareer academics: CAS- and HEI-based PhD candidates, $\mathrm{HEI}$-based postdocs and researchers (regardless of the field), CAS-based research associates, and postdoc researchers in STEM.

In SSH fields, unlike in STEM, most CAS-based research associates and postdocs were found in the semiperiphery. This is probably because there is more autonomy and job security during the postdoc stage in $\mathrm{SSH}$ fields than in STEM. Among CAS-based research associates and postdocs in STEM there were more part-timers (19\% STEM vs $10 \%$ SSH), more CRS academics (over $55 \%$ in STEM and $30 \%$ in SSH), fewer opportunities to influence important features of work, and less satisfaction among staff with the use of their skills than what was observed among their counterparts in $\mathrm{SSH}$ fields.

A total of $28 \%$ of respondents worked in the periphery. This segment consists predominantly of men (58.8\%) and young people (31.6y on average). A special subcategory of the periphery was made up of HEl-based PhD candidates with employee status, who rank lowest in terms of job quality and stability. The overwhelming majority of periphery employees were working part-time (about $70 \%)$ and very few had a long-term or permanent contract (8\%). More than $54 \%$ of these positions are occupied by CRS. The least job satisfaction and job autonomy is observed in the periphery (see Supplementary File, Table 1).

Many of these findings are not surprising given the junior status of $\mathrm{PhD}$ candidates. What is disturbing is that periphery academics scores high on mental and physical exhaustion and stress (see also, e.g., Waaijer et al., 
2018) and receive little collegial support, especially at HEls, according to our data.

The smallest gender differences in working conditions are in the periphery, where they can be attributed mainly to the type of institution and to the field. Nevertheless, it is important to note that even if this segment consists mainly of $\mathrm{PhD}$ candidates, there are still far more women $\mathrm{PhD}$ graduates in the periphery than men $\mathrm{PhD}$ graduates (16.6\% of all women $\mathrm{PhD}$ graduates are here, compared to $8.3 \%$ of men PhD graduates).

Institutional differences show that working conditions in the periphery are much better in the CAS than in HEls. This is true in terms of job security, wages, and organisational citizenship. Periphery academics at the CAS have higher wages, in most cases at least a 3-year contract, and heavier workloads than periphery academics at HEls. This means that they are paid for most of the time that they spend working-the data show that the smaller the official workload, the more non-paid overtime an academic was performing (Vohlídalová, 2018). Conversely, more CAS-based researchers, especially in STEM fields, were found to be a CRS.

Important differences were observed in the organizational citizenship. CAS-based periphery academics reported receiving a higher level of support from colleagues and higher satisfaction with the use of their skills at work. HEI-based periphery academics were $38 \%$ less likely to feel supported by colleagues and $48 \%$ less likely to be satisfied with the use of their skills at work than their CAS counterparts (see Supplementary File, Table 2).

The field affects mostly the number of hours worked (people in STEM fields work on average 5.6 hours/week more than people in SSH). However, there were no statistically significant differences in the workload officially stated in the work contract, suggesting that STEM academics work more overtime than SSH academics. This is especially true for PhD candidates.

\section{Discussion}

Hierarchical cluster analysis yielded three main labourmarket segments differentiated by working conditions and job security, which generally correspond to the early, middle, and senior stages of an academic career. Just under $40 \%$ of Czech academics work in the core segment of the academic market, and they include CAS-based senior researchers and $\mathrm{HEI}$-based full/associate professors. The periphery contained $28 \%$ of respondents, who were in positions with unfavourable working conditions (PhD candidates at the CAS and HEIs, CAS-based research associates, postdoc researchers in STEM, and HEI-based postdocs and researchers). Finally, 32\% of respondents worked in positions in the semi-periphery (HEI-based assistant professors, CAS-based postdocs and research associates in SSH, HEl-based lecturers/instructors). The semi-periphery provided higher pay and better career prospects than the casualised periphery, but working conditions were much worse than in the core.
The smallest gender differences across the ALM were found in the periphery, suggesting that the gender gap in working conditions is not as pronounced at the start of an academic career as it becomes later. The working conditions in the periphery appeared to be equally unfavourable for men and women. This changes noticeably at the mid-career level in the semi-periphery, where gender becomes a key factor affecting inequalities in working conditions.

Women in the semi-periphery declare less favourable working conditions than men and, like women in the core, lower wages. Although there were no significant gender differences in objective indicators of job security (i.e., type of contract), women in the semi-periphery scored much worse than men on subjective indicators of job security. They also declare less work autonomy and more stress and exhaustion than men. This explains why it is at this stage of an academic career that women leave academia at the highest rates (Cidlinská, 2019). One key reason for this, well addressed in current research, is the incompatibility of an academic career with private life demands, because this career stage usually coincides with the most childcare-intensive period of life (Dubois-Shaik \& Fusulier, 2017; González Ramos et al., 2015). This is a particularly topical issue for Czech academics (see, e.g., Linková, 2017; Vohlídalová, 2020; Zábrodská et al., 2017). The semi-periphery is thus the key segment that needs to be targeted by any policies seeking to address the leaky-pipeline problem. Analysis suggests that academic institutions should play more attention to gender inequalities in the distribution of teaching loads among staff in semi-periphery positions, especially in STEM fields.

In the core, the effect of gender on working conditions is barely visible in our data, with one important exception-wage differences. Even when controlling for the effect of field and institution, women in the core had lower wages than men. Given the lack of statistical data on gender inequalities in wages in Czech academia, the gender wage gap in academia should be researched in more detail in the future, focusing particularly on the role of seniority, field, and institution.

The academic institutions involved in the analysis represent two types: a purely competitive research-oriented institution (CAS) and HEls with a hybrid system. HEls are combining (1) the competitive approach that applied mostly to junior and mid-level academics with a 'feudal' model that supports and protects senior academics regardless of their work performance (see Mudrák et al., 2018), and (2) teaching and research. Our findings suggest that at HEls the privileged position enjoyed by full/associate professors is 'offset' by the disadvantaged working conditions experienced by lower-ranking academics. In the CAS, conversely, a degree of casualisation applies even to senior academics in the core segment, and at the same time it offers much better working conditions at the start of an academic career than the HEls do. This is the case in terms of both work contract and 
organisational citizenship indicators (support from colleagues particularly). This suggests the hypothesis that in the more 'egalitarian' (i.e., there is no highly privileged group) and purely research-oriented institutions, lowerranking academics may benefit more from their work environment than they do at teaching-oriented institutions. As Fumasoli and Goastellec (2015) note, researchoriented institutions are better at integrating young academics into the academic environment. Our data suggest that they also provide them with better support and working conditions. However, this may be unique to Czech academia and further research is needed to better understand the link between the type of institution and working conditions.

The biggest differences in working conditions by field are seen in wages (except in the periphery), with significantly higher wages in STEM fields than SSH, and in work casualisation. The data show that STEM academics (even within the core segment) are more often employed as CRS and have short-term work contracts than SSH academics. This suggests differences in the expectations and meanings associated with individual career stages in STEM and SSH. While for STEM the postdoc positions at the CAS were mainly clustered in the periphery (mainly because of short-terms contracts), for SSH the same positions were clustered in the semi-periphery. This could mean that in SSH fields a postdoc position is associated with greater autonomy and independence, and if a person finds a job in SSH it is likely to be a more stable (but worse paid) than is the case in STEM fields. To conclude, my findings support the thesis that the neoliberal transformation of the ALM is more visible in STEM than in SSH fields (Ylijoki et al., 2011). However, it is important to note that the labour market in STEMs field is much larger, because disproportionately more money goes to these fields (at least in the Czech Republic), which probably makes it easier to find a job and earn better wages than in $\mathrm{SSH}$.

\section{Conclusion}

My article proposes an innovative methodology for studying the structure of the ALM that identifies different ALM segments. It is based on a complex operationalisation of job quality, which can be easily adapted to any academic environment. This approach could be particularly useful for studying environments where no clear divisions exist between the core and periphery segments and for comparative studies of countries with variability in the R\&D systems. This methodology goes beyond the core-periphery division to attain a more nuanced analysis of inequalities in the ALM.

My study contributes to the large body of research on ALM inequalities that has focused on inequalities and working conditions in specific stages of an academic career (e.g., Bagilhole \& Goode, 2001; Bataille et al., 2017; Bozzon et al., 2017; Cidlinská, 2019; O’Connor, 2010) with a comparative perspective. It demonstrates that (1) gender, field, and institutional inequalities manifest differently in different segments of the ALM and (2) the impact of these characteristics on working conditions also varies between segments of the ALM. This finding can help in designing and targeting effective tailormade policies in support of fair working conditions and gender equality across different career stages.

Bauder (2006) believes that the casualisation of working conditions in academia will continue and that the core will eventually be absorbed by the periphery. Based on my findings, this may particularly be the case of research institutes (such as the CAS) in the Czech Republic, where a certain level of the casualisation is already evident even in the core. While some form of tenured core should continue to exist at HEls, but we can expect stronger institutional barriers that will prevent mobility between the periphery and the core. In recent years, this trend has taken the form of increasingly stringent conditions being applied to the habilitation process that academics must go through to obtain a core position at a HEls (Šima \& Pabian, 2017).

Furthermore, in the wake of the COVID-19 crisis, a general decline of government expenditure is expected in the Czech Republic, along with austerity measures in the R\&D and HEl sectors. My analysis suggests that the trend of ALM casualisation can be expected to affect different segments, fields, types of institution, and men and women in different ALM segments in different ways.

\section{Acknowledgments}

I would like to thank Kateřina Cidlinská and three anonymous reviewers and academic editors for their valuable comments. This article was supported by the project IGA 2021 "Publishing Support of the Department of Economics and Management for the Year 2021" (AMBIS University). The data ("Academics 2017") were collected as part of the work on project number CZ.03.1.51/0.0/0.0/15_028/0003571 funded by the European Union from the European Social Fund, under the Operational Programme Employment in 2017-2018.

\section{Conflict of Interests}

The author declares no conflict of interests.

\section{Supplementary Material}

Supplementary material for this article is available online in the format provided by the author (unedited).

\section{References}

Atkinson, J. (1984). Manpower strategies for flexible organisations. Personnel Management, 16, 28-31.

Acker, J. (1990). Hierarchies, jobs, bodies: A theory of gendered organizations. Gender \& Society, 4(2), 139-158. 
Bagilhole, B., \& Goode, J. (2001). The contradiction of the myth of individual merit, and the reality of a patriarchal support system in academic careers. European Journal of Women's Studies, 8(2), 161-180.

Bataille, P., Le Feuvre, N., \& Kradolfer Morales, S. (2017). Should I stay or should I go? The effects of precariousness on the gendered career aspirations of postdocs in Switzerland. European Educational Research Journal, 16(2/3), 313-331.

Bauder, H. (2006). The segmentation of academic labour: A Canadian example. ACME: An International E-Journal for Critical Geographies, 4(2), 228-239.

Becher, T., \& Trowler, P. (2001). Academic tribes and territories. The Society for Research into Higher Education.

Bozzon, R., Murgia, A., Poggio, B., \& Rapetti, E. (2017). Work-life interferences in the early stages of academic careers: The case of precarious researchers in Italy. European Educational Research Journal, 16(2/3), 332-351.

Cidlinská, K., \& Linková, M. (2013). “Ekonomie př́slibu: pracovní nejistota a gender na počátku vědecké dráhy" [The economics of promise: Job uncertainty and gender at the beginning of a scientific career]. In M. Linková, K. Cidlinská, H. Tenglerová, M. Vohlídalová, \& A. Červinková (Eds.), Nejisté vyhlídky. Proměny vědecké profese z genderové perspektivy [Uncertain prospects: A gendered perspective on changes in the scientific profession] (pp. 51-80). SLON.

Cidlinská, K. (2019). How not to scare off women: Different needs of female early-stage researchers in STEM and $\mathrm{SSH}$ fields and the implications for support measures. Higher Education, 78(2), 365-388.

Courtois, A., \& O'Keefe, T. (2015). Precarity in the ivory cage: Neoliberalism and casualisation of work in the Irish higher education sector. Journal for Critical Education Policy Studies, 13(1), 43-66.

Czech Academy of Sciences. (2020). Výroční zpráva [Annual report]. http://pdf.avcr.cz/VZ/2020/\#page=1

Czech Statistical Office. (2020). Ukazatele výzkumu a vývoje 2019 [Research and development indicators 2019]. https://www.czso.cz/csu/czso/1-ukazatelevav-za-ceskou-republiku-celkem-7572pshnmm

Dubois-Shaik, F., \& Fusulier, B. (2017). Understanding gender inequality and the role of the work/family interface in contemporary academia: An introduction. European Educational Research Journal, 16(2/3), 99-105.

Durodoye, R., Gumpertz, M., Wilson, A., Griffith, E., \& Ahmad, S. (2020). Tenure and promotion outcomes at four large land grant universities: Examining the role of gender, race, and academic discipline. Research in Higher Education, 61(5), 628-651.

European Commission. (2019). She figures 2018. Luxembourg Publication Office of the EU.

European Commission and Eurydice Network. (2017). Modernisation of higher education in Europe: Aca- demic staff-2017 (Eurydice Report). Publications Office of the European Union.

Finnegan, D. E. (1993). Segmentation in the academic labor market: Hiring cohorts in comprehensive universities. The Journal of Higher Education, 64(6), 621-656.

Fox, M. F., Fonseca, C., \& Bao, J. (2011). Work and family conflict in academic science: Patterns and predictors among women and men in research universities. Social Studies of Science, 41(5), 715-735.

Fox, M. F., Linková, M., \& Bunker Whittington, K. (2017). Gender, (in)equity, and the scientific workforce. In U. Felt, R. Fouché, C. A. Miller, \& L. Smith-Doerr (Eds.), The handbook of science and technology studies (4th ed.; pp. 701-732). The MIT Press.

Fumasoli, T., \& Goastellec, G. (2015). Global models, disciplinary and local patterns in academic recruitment processes. In T. Fumasoli, G. Goastellec, \& B. M. Kehm (Eds.), Academic work and careers in Europe: Trends, challenges, perspectives (pp. 69-93). Springer International Publishing.

Fumasoli, T., Goastellec, G., \& Kehm, B. M. (Eds.). (2015). Academic work and careers in Europe: Trends, challenges, perspectives. Springer International Publishing.

González Ramos, A. M., Navarrete Cortés, J., \& Cabrera Moreno, E. (2015). Dancers in the dark: Scientific careers according to a gender-blind model of promotion. Interdisciplinary Science Reviews, 40(2), 182-203.

Hall, L. (2010). “The problem that won't go away “: Femininity, motherhood and science. Women's Studies Journal, 24(1), 14-30.

Ivancheva, M. (2015). The age of precarity and the new challenges to the academic profession. Studia Europaea, 60(1), 39-47.

Ivancheva, M., Lynch, K., \& Keating, K. (2019). Precarity, gender and care in the neoliberal academy. Gender, Work and Organization, 26(4), 448-462.

Jackson, J. K., Latimer, M., \& Stoiko, R. (2017). The dynamic between knowledge production and faculty evaluation: Perceptions of the promotion and tenure process across disciplines. Innovative Higher Education, 42(3), 193-205.

Kimber, M. (2003). The tenured "core" and the tenuous "periphery": The casualisation of academic work in Australian universities. Journal of Higher Education Policy and Management, 25(1), 41-50.

Kwiek, M., \& Antonowicz, D. (2015). The changing paths in academic careers in European universities: Minor steps and major milestones. In T. Fumasoli, G. Goastellec, \& B. M. Kehm (Eds.), Academic work and careers in Europe: Trends, challenges, perspectives (pp. 41-68). Springer International Publishing.

Leišytė, L. (2016). New public management and research productivity-A precarious state of affairs of academic work in the Netherlands. Studies in Higher Education, 41(5), 828-846. 
Leontaridi, M. R. (1998). Segmented labour markets: Theory. Journal of Economic Surveys, 12(1), 63-102.

Linková, M. (2017). Excellence and its others: Gendered notions of what it takes to succeed in science. In M. Vohlídalová \& M. Linková (Eds.), Gender and neoliberalism in Czech academia (pp. 159-197). SLON.

Linková, M., \& Červinková, A. (2013). “Vlastní laboratoř": Akademické trajektorie a gender v současných biovědách ["A lab of one's own": Academic trajectories and gender in contemporary biosciences]. Gender, rovné př́ležitosti, výzkum, 14(1), 15-26.

Linková, M., \& Stöckelová, T. (2012). Public accountability and the politicization of science: The peculiar journey of Czech research assessment. Science and Public Policy, 39(5), 618-629.

Luczaj, K. (2020). Overworked and underpaid: Why foreign-born academics in central Europe cannot focus on innovative research and quality teaching. Higher Education Policy. Advance online publication. https://doi.org/10.1057/s41307-020-00191-0

Macfarlane, B., \& Burg, D. (2019). Women professors and the academic housework trap. Journal of Higher Education Policy and Management, 41(3), 262-274.

Mason, M. A., \& Goulden, M. (2004). Marriage and baby blues: Redefining gender equity in the academy. The Annals of the American Academy of Political and Social Science, 596, 86-103.

May, R., Peetz, D., \& Strachan, G. (2013). The casual academic workforce and labour market segmentation in Australia. Labour \& Industry: A Journal of the Social and Economic Relations of Work, 23(3), 258-275.

Mudrák, J., Zábrodská, K., Květoň, P., Jelínek, M., Blatný, M., Šolcová, I., \& Machovcová, K. (2018). Occupational well-being among university faculty: A job demands-resources model. Research in Higher Education, 59(3), 325-348.

Musselin, C. (2005). European academic labor markets in transition. Higher Education, 49(1/2), 135-154.

O'Connor, P. (2010). Is senior management in Irish universities male-dominated? What are the implications? Irish Journal of Sociology, 18(1), 1-21.

O'Keefe, T., \& Courtois, A. (2019). 'Not one of the family': Gender and precarious work in the neoliberal university. Gender, Work and Organization, 26(4), 463-479.

Oates-Indruchová, L. (2008). The limits of thought? The regulatory framework of social sciences and humanities in Czechoslovakia (1968-1989). EuropeAsia Studies, 60(10), 1767-1782.

Passaretta, G., Trivellato, P., \& Triventi, M. (2019). Between academia and labour market-The occupational outcomes of $\mathrm{PhD}$ graduates in a period of academic reforms and economic crisis. Higher Education, 77(3), 541-559.

Rhoton, L. A. (2011). Distancing as a gendered barrier: Understanding women scientists' gender practices. Gender \& Society, 25(6), 696-716.

Shore, C. (2008). Audit culture and illiberal governance universities and the politics of accountability. Anthro- pological Theory, 8(3), 278-298.

Shore, C., \& Wright, S. (2015). Audit culture revisited: Rankings, rankings, ratings, and the reassembling of society. Current Anthropology, 56(3), 421-444.

Šima, K., \& Pabian, P. (2017). Higher education policy context. In M. Vohlídalová \& M. Linková (Eds.), Gender and neoliberalism in Czech academia (pp. 93-118). SLON.

van den Brink, M., \& Benschop, Y. (2011). Gender practices in the construction of academic excellence: Sheep with five legs. Organization, 19(4), 507-524.

van den Brink, M., \& Benschop, Y. (2012). Slaying the seven-headed dragon: The quest for gender change in academia. Gender, Work \& Organization, 19(1), 71-92.

van den Brink, M., \& Benschop, Y. (2014). Gender in academic networking: The role of gatekeepers in professorial recruitment. Journal of Management Studies, 51(3), 460-492.

United Nations. (2015). Handbook on measuring quality of employment. A statistical framework. https:// unece.org/fileadmin/DAM/stats/publications/2015/ ECE_CES_40.pdf

Vohlídalová, M. (2018). Akademici a akademičky 2018: Zpráva z dotazníkového šetření akademických a vědeckých pracovnic a pracovníků ve veřejném sektoru [Academics 2018: Research report from the survey on academics and researchers working in the public sector]. Institute of Sociology, Czech Academy of Sciences. https://www.soc.cas.cz/sites/default/ files/soubory/akademici_a_akademicky_2018__zprava_z_dotaznikoveho_setreni.pdf

Vohlídalová, M. (2020). Early-career women academics: Between neoliberalism and gender conservatism. Sociological Research Online, 26(1), 27-43.

Vohlídalová, M., \& Linková, M. (2017). Gender and neoliberalism in Czech academia. SLON.

Waaijer, C. J. F., Teelken, C., Wouters, P. F., \& Van Der Weijden, I. C. M. (2018). Competition in science: Links between publication pressure, grant pressure and the academic job market. Higher Education Policy, 31(2), 225-243.

Wennerås, C., \& Wold, A. (1997). Nepotism and sexism in peer-review. Nature, 387(6631), 341-343.

Wilson, F., \& Nutley, S. (2003). A critical look at staff appraisal: The case of women in Scottish universities. Gender, Work and Organization, 10(3), 301-319.

Wolf-Wendel, L., \& Ward, K. (2014). Academic mothers: Exploring disciplinary perspectives. Innovative Higher Education, 40(1), 19-35.

Wolfinger, N., Mason, M., \& Goulden, M. (2009). Stay in the game: Gender, family formation and alternative trajectories in the academic life course. Social Forces, 87(3), 1591-1621.

Ylijoki, O.-H. (2010). Future orientations in episodic labour: Short-term academics as a case in point. Time \& Society, 19(3), 365-386.

Ylijoki, O. H., Lyytinen, A., \& Marttila, L. (2011). Different 
research markets: A disciplinary perspective. Higher Education, 62(6), 721-740.

Zábrodská, K., Mudrák, J., Šolcová, I., Květon, P., Blatný, M., \& Machovcová, K. (2017). Burnout among university faculty: The central role of work-family conflict.
Educational Psychology, 38(6), 1-20.

Zheng, R. (2018). Precarity is a feminist issue: Gender and contingent labor in the academy. Hypatia, 33(2), 235-255.

\section{About the Author}

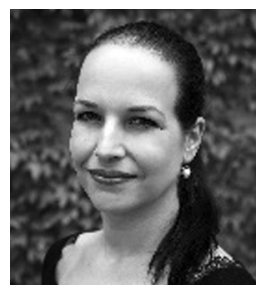

Marta Vohlídalová (PhD) is an Assistant Professor in Sociology at AMBIS University, Prague, and a Researcher in the Gender and Sociology Department at the Institute of Sociology, Academy of Sciences of the Czech Republic. She focuses on the gender aspects of an academic career and academic mobility, gender equality in the labour market, family policies, work-life balance, and sexual harassment in higher education. https://www.researchgate.net/profile/Marta-Vohlidalova 